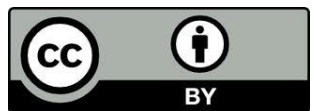

\title{
O MITO DA SECULARIZAÇÃO E A REPRODUÇÃO DA MORAL RELIGIOSA NO BRASIL: UM DESAFIO PARA AS ESCOLAS PÚBLICAS?
}

\author{
The Myth of Secularisation and Reproduction of Moral Religious in Brazil: A Challenge \\ for Public Schools?
}

\author{
Ileizi Luciana Fiorelli Silva \\ Universidade Estadual de Londrina \\ Professora Doutora do Departamento de Ciências Sociais \\ Franciele Rodrigues \\ Universidade Estadual de Londrina \\ Mestranda Programa de Pós-Graduação em Ciências Sociais \\ Programa Observatório da Educação (OBEDUC) \\ Coordenação de Aperfeiçoamento de Pessoal de Nível Superior (CAPES)
}

\begin{abstract}
RESUMO: Este trabalho tem como propósitos conhecer quais os pertencimentos religiosos de estudantes do ensino médio vinculados a duas escolas públicas situadas em Londrina-PR e refletir sobre quais são as percepções destes sujeitos acerca das uniões homoafetivas e a presença dos símbolos religiosos no ambiente escolar. Para tanto, nosso caminho metodológico foi o desenvolvimento, aplicação e análise de questionários. Constatamos a predominância de alunos cristãos, contrários a formação de casais do mesmo sexo e, majoritariamente favoráveis ou indiferentes a existência dos objetos religiosos nas instituições escolares. Com isto, vislumbramos a reprodução das formas religiosas de interpretar o mundo e dos valores religiosos para a organização da vida privada e social.
\end{abstract}

Palavras chave: Religião; Moral; Escolas.

ABSTRACT: This work has the purpose to know which religious affiliations of high school students linked to two public schools located in Londrina and reflect on what are the perceptions of these subjects about homoafetivas unions and the presence of religious symbols at school. Therefore, our methodological approach was the development, application and analysis of questionnaires. We note the predominance of Christian students, opposed the formation of same-sex couples and mostly favorable or indifferent to the existence of religious objects in schools. With this, we glimpse the reproduction of religious ways of interpreting the world and religious values for the organization of private and social life.

Keywords: Religion; Moral; Schools. 


\section{Introdução}

As teorias, os conceitos e métodos das diferentes ciências se renovam com o passar dos anos. Especificamente no campo das Ciências Sociais, o diálogo entre as ideias formuladas e o que é observado acerca dos fenômenos sociais no cotidiano é o que tem garantido a "eterna juventude" a área, tal como dito por um daqueles que é considerado seu sociólogo clássico, Max Weber.

Assim, tem sido com a teoria da secularização no âmbito da Sociologia das Religiões, cujos pesquisadores brasileiros mediante a análise de dados empíricos e peculiares à nossa realidade social têm indagado: no Brasil as religiões perderam sua importância na atualidade? As referências religiosas restringiram-se a vida privada ou também as encontramos nos espaços públicos?

A procura pelas respostas a estas perguntas tem levado a verificação de que na sociedade brasileira as religiões não desapareceram tampouco foram substituídas completamente pela racionalidade de modo que elementos seculares e mágicos coexistem na vida indivíduos. Isto quer dizer, que o processo de secularização não ocorreu de forma homogênea para todos os lugares do mundo.

Com base neste entendimento, buscaremos refletir neste trabalho, em um primeiro momento, sobre a presença das religiões na formação das esferas públicas. Posteriormente, pensaremos sobre a reprodução de uma moral religiosa na sociedade brasileira e de que forma ela está presente dentro de um espaço público em especial: as escolas.

Para tanto, apresentaremos resultados de uma pesquisa exploratória realizada pela parceria do Laboratório de Estudos sobre as Religiões e Religiosidades (LERR) com o Programa Observatório da Educação (OBEDUC), ambos vinculados a Universidade Estadual de Londrina (UEL) cujo objetivo geral foi conhecer as percepções dos estudantes do ensino médio da rede estadual de Londrina-PR acerca das relações entre educação e religião, diversidades, cultura e participação política ${ }^{1}$.

\footnotetext{
${ }^{1}$ Informamos que por meio da pesquisa foram coletadas 560 amostras envolvendo estudantes de 11 escolas. Para o desenvolvimento deste artigo foram utilizadas 107 amostras de duas escolas localizadas nas regiões Oeste e Norte da cidade.
} 


\section{Apontamentos sobre o pluralismo religioso brasileiro nas esferas públicas}

O campo religioso brasileiro é marcado pela multiplicidade de crenças e ritos que diversificam as expressões religiosas ao mesmo tempo em que os processos sincréticos as aproximam pelo compartilhamento de elementos umas das outras. Diante disso e partindo do entendimento de que o ideal de secularização de perspectiva weberiana $^{2}$, segundo o qual, o retraimento da religião ocorreria na medida em que a modernidade se desenvolvesse não ocorreu no Brasil, torna-se preponderante refletir sobre as presenças e, sobretudo, as ausências das diferentes matrizes religiosas nos espaços públicos, isto é, a diversidade religiosa encontra-se representada nestes locais coletivos ou eles são apropriados por apenas algumas religiões?

Nesta perspectiva, Paula Monteiro em sua reflexão: "Religião, Pluralismo e Esfera Pública no Brasil" (2006) nos trouxe algumas problemáticas a serem pensadas. Neste, a intenção da autora foi demonstrar que a separação entre Estado e Igreja Católica, não levou ao desaparecimento dos traços e referências religiosas da vida social na sociedade brasileira, de modo que as religiões não se restringiram aos domínios da vida privada, particular, doméstica, ao contrário, ainda exercem grande influência nos espaços públicos e coletivos. Recorrendo as suas explicações: "buscaremos ainda mostrar que tal processo não redundou na retirada das religiões do espaço público, ao contrário, resultou na produção de novas formas religiosas, com expressão pública variável conforme o contexto e suas formas específicas de organização institucional (MONTEIRO, 2006, p.50).

Monteiro (2006) chamou atenção para a influência da Igreja Católica na formação da esfera pública no Brasil bem como nas relações entre esta e as demais expressões religiosas. Segundo ela, desde a formação do Estado republicano brasileiro, a perseguição as práticas religiosas de indígenas, negros ${ }^{3}$, mulatos e imigrantes acusados de feitiçaria, charlatanismo, curandeirismo já demonstravam a tendência a normatização das diferentes crenças religiosas aos princípios da religião cristã e sua respectiva moralidade religiosa.

\footnotetext{
2 Para aprofundamento deste assunto, sugerimos a leitura do ensaio: "Secularização em Max Weber da contemporânea serventia de voltarmos a acessar aquele velho sentido" (1998) do professor Antônio Flávio Pierucci.

${ }^{3}$ Acerca deste assunto, Bastide (1985) afirmou: "Vimos que para poder subsistir durante todo o período escravista os deuses negros foram obrigados a se dissimular por trás da figura de um santo ou de uma virgem católica" (BASTIDE, 1985, p.359).
} 
Retrocedendo ainda mais na história do Brasil, Camurça (2009) esclareceu que desde o período colonial o universo religioso europeu, predominantemente católico, buscou assimilar a cultura nativa dos indígenas e dos africanos que chegaram por aqui. Em outras palavras, "contaminações mútuas" entre as crenças e práticas católicas, indígenas e africanas ocorreram desde o processo de formação do Brasil, entretanto, é importante destacar que este não foi um diálogo sem conflito e nem mesmo igualitário, isto porque, todas as religiões deviam assemelhar-se e compatibilizar suas práticas e crenças ao catolicismo.

Dito com outras palavras, a formação do cenário religioso brasileiro, desde a constituição do Estado e da sociedade civil, se deu pela repressão e deslegitimidade das experiências religiosas populares e não institucionalizadas frequentemente associadas às ideias de magia e que, por sua vez, eram vistas como ameaçadoras do status quo. Há que se ressaltar que foi sobre as bases desta moral cristã, e, sobretudo, católica, que se estabeleceram os entendimentos historicamente e socialmente formulados do que podia ser aceito como religião.

Se a liberdade religiosa foi cronologicamente a "primeira" a que serviu de modelo para todas as outras formas de liberdade civil, a constitucionalidade jurídica da República se viu às voltas com o problema de separar, no confuso quadro das práticas da população o que era "religião", portanto, com direito a proteção legal, daquilo que era "magia", prática anti social e anômica a ser combatida (MONTEIRO, 2006, p.51).

Diante desta supremacia da religião católica no campo religioso brasileiro, Monteiro (2006) questionou: “mas se religião consistia consensualmente apenas naqueles cultos praticados pela Igreja Católica, como regulamentar as outras práticas que se expressavam no espaço público?” (MONTEIRO, 2006, p.53). Mencionamos um dos exemplos trazidos por ela, acerca das religiões afro-brasileiras que associadas à ideia de "macumba", de "feitiço", conseguiram sobreviver à repressão por meio do sincretismo afro-católico e a sua conversão em religião escondendo-se atrás das crenças do espiritismo, cujas práticas eram mais facilmente aceitas do que as suas depreciadas como "magia negra", haja vista que suas experiências religiosas, como danças e transes eram tidos como formas de demonização pela Igreja Católica.

Dessa forma, observa-se que os confrontos pelo alcance da liberdade religiosa, base para a formação do espaço civil republicano, não se encaminharam para o sentido de: "qual religião teria a liberdade, mas quase sempre sobre a liberdade de que 
desfrutaria a religião católica, uma vez que não havia então qualquer outro culto estabelecido, nem se concebiam outras práticas populares como religiosas" (MONTEIRO, 2006, p.52).

Ainda para Monteiro (2006) tendo o catolicismo se constituído uma espécie de “[...] língua universal da tradução de qualquer prática em rito religioso e o referencial de uma publicização legítima" (MONTEIRO, 2006, p.61) a auto-representação de mães, pais de santo, e espíritas como católicos não foi incomum e de igual maneira a conversão de terreiros de candomblé, centros espíritas, tendas de umbanda ao estatuto de religiões foi enxergado como um movimento natural por meio da qual tais matrizes religiosas foram aos poucos se institucionalizando como religiões. Todavia, é necessário desmistificar que este processo compõe um cenário de disputa em que os diferentes fenômenos religiosos com forças sociais em desequilíbrio se enfrentaram pela instauração de um modelo de sociedade e dos valores morais nela compartilhados.

Camurça (2009) também esclareceu que a partir das décadas de 1960 e 1970 consolidando-se nos anos seguintes de 1980 e 1990 um novo fenômeno ocorreu no universo religioso brasileiro chamado de "pluralismo institucional", decorrente do surgimento do pentecostalismo e neopentecostalismo nos anos 60 e 70 e do movimento carismático nos anos 80 e 90. Com isto, as diferentes denominações religiosas formaram uma espécie de "mercado religioso", tal como identificado por Peter Berger (1985) e passaram, a adotar uma dinâmica abertamente competitiva, haja vista que as religiões passaram a estabelecer estratégias de mercado a fim de manter os que já eram seus seguidores e aumentar tanto mais seus membros. A passagem a seguir exemplifica este entendimento:

[...] No campo evangélico, o fato de as igrejas evangélicas clássicas modificarem-se litúrgica e doutrinariamente na direção (neo)pentecostal para ficarem mais competitivas em relação aos neopentecostalismos; no campo católico, o papel da renovação carismática católica buscando dar a igreja mais visibilidade na esfera pública através de técnicas emocionais, lúdicas e midiáticas muito próximas dos pentecostais, adestrando a instituição a competir no mercado religioso na conquista e preservação de seus fiéis (CAMURÇA, 2009, p.179).

No entanto, ambos os autores, afirmaram que se no plano das instituições religiosas as lutas concorrenciais e tensões por legitimação foram verificáveis, já para os indivíduos estas "fronteiras" parecem desaparecer, isto porque, os sujeitos tendem a combinar práticas, rituais, crenças de diferentes religiões de forma estratégica e 
conjuntural para as suas necessidades contextuais: "todas as religiões são boas, mas cada qual para uma ocasião" (MONTEIRO, 2006, p.61) sem que isso necessariamente leve em uma mudança em plano institucional. Por exemplo, um católico pode frequentar a missa aos domingos e ao mesmo tempo em que devido a um problema de ordem financeira procura as reuniões da prosperidade ocorridas no âmbito da Igreja Universal do Reino de Deus (IURD) sem que necessariamente torne-se membro desta última.

Logo, os indivíduos compõem suas religiões e religiosidades de forma personalizada, isto é, de acordo com suas preferências e necessidades, mesmo que para isso venham a combinar práticas e símbolos religiosos de diferentes denominações. Assim, o que se vê é a hibridização das crenças religiosas na modernidade e não a tendência a secularização.

Deste modo, ressaltam os autores que o paradigma weberiano sobre a ideia de secularização, não é cabível a realidade brasileira, haja vista que nas esferas públicas tem se percebido a manutenção dos valores religiosos cristãos e, sobretudo, católicos como explicativos e ordenadores dos comportamentos humanos.

\section{O mito da secularização}

A fim de compreendermos a construção do Estado secular na sociedade brasileira contemporânea precisamos de antemão considerar as relações que religião e política estabeleceram em momentos históricos antecessores. Como é sabido durante o período imperial a laicidade não existia no Brasil, basta ver que o catolicismo era tido como religião oficial de modo que as outras religiões eram proibidas de realizar cultos públicos, sendo não raro, perseguidas pela polícia acusadas de práticas de feitiçaria, como explicamos anteriormente. Além disso, também neste momento, o clero católico recebia salários por parte do governo.

Já com advento do regime republicano oficialmente Estado e religião foram separados. Todavia, as referências religiosas não desapareceram. A última Constituição promulgada, em 1988, por exemplo, apesar de em seu conteúdo conceber um Estado secular, traz em seu preâmbulo: “[...] promulgamos sobre a proteção de Deus, a seguinte Constituição da República Federativa do Brasil”.

Assim, segundo Mariano (2011) os debates acerca das ideias de laicidade e secularização intensificaram-se nas últimas três décadas decorrentes, entre outras 
causas, da expansão da Teologia da Libertação e do pentecostalismo na América Latina bem como do surgimento de novos fenômenos religiosos atrelados a crescente participação de grupos religiosos nas esferas públicas.

Diante disso, pesquisadores dentro e fora do Brasil viram-se frente ao desafio de repensar o papel das religiões na sociedade contemporânea, uma vez que a teoria da secularização, amplamente defendida no campo das Ciências Sociais até a década de 1960, e que compreendia o florescer de uma sociedade secular como consequência dos movimentos de modernização, cujos efeitos levariam a extinção da religião, passou a ser questionada não só no âmbito da Sociologia das Religiões: "deram margem, inclusive, à interpretação de que teríamos ingressado numa era pós-secular [...]" (MARIANO, 2011, p.239).

Neste sentido, entre seus opositores, uma das críticas direcionadas a teoria da secularização discordava da forma como as análises sociológicas foram encaminhadas de modo que religião e modernidade foram vistas como fenômenos incompatíveis, ou seja, ao passo que as sociedades se modernizassem, alcançassem avanços tecnológicos e o progresso, o conhecimento cientifico tenderia a substituir a religião e suas formas de compreender e significar o mundo.

[...] Perceberam o crescimento do secularismo como uma via de mão única para a modernização, como fenômeno positivo, concomitantemente com a expansão da ciência, da educação e da tecnologia e com a crença otimista no progresso e na obtenção, seja pela via reformista ou pela via revolucionária, de crescente bem-estar material da população, fenômenos que tenderiam a minar a necessidade de explicações religiosas do mundo, a necessidade coletiva de consolo religioso e a pôr em xeque a existência de organizações religiosas, senão da própria religião (MARIANO, 2011, p.242).

No entanto, Mariano (2011) é contrário a esta teoria diretiva e unilinear de mudança social ${ }^{4}$, tal qual entende o processo de secularização como universal e que estabeleceu a Europa como referencial de sociedade secularizada a ser seguido, pois ela desconsidera as peculiaridades sócio-históricas e culturais de cada país e, que por sua vez, são preponderantes para compreendermos como as relações entre os Estados e as religiões foram construídas em cada realidade social específica, por exemplo, a influência da Igreja Católica na sociedade brasileira ${ }^{5}$. Dito de outra forma, segundo o

\footnotetext{
${ }^{4}$ Sobre as diferentes perspectivas da teoria da mudança social sugerimos a leitura do texto: "Teorias da mudança social: As perspectivas lineares e as cíclicas" (2002), de Maria José de Rezende.

${ }^{5}$ São algumas sugestões para leitura: "História Geral da Igreja na América Latina" de Eduardo Hoornaert e "A Elite Eclesiástica Brasileira" de Sérgio Miceli.
} 
autor, é preciso ponderar que os fenômenos da modernidade e da secularização possuem diferentes sentidos de modo que devemos considerá-los como plurais e heterogêneos e não como se houvesse uma onda secular que atingiria de igual maneira todo o mundo.

Destarte, o autor nos alertou também sobre a necessidade de compreendermos as noções de "laicidade" e de "secularização" como meios para analisarmos as interações entre religião e política, igreja e Estado, segmentos religiosos e laicos. Buscando estabelecer diferenciações entre eles, em síntese, Mariano (2011), entendeu o primeiro como a independência do Estado de quaisquer referência e influência religiosa, isto é, o poder político em um Estado laico passa a ter autonomia frente ao poder religioso. Além disso, cabe também a um Estado laico estabelecer a isonomia frente às diversas expressões religiosas, garantir a liberdade religiosa, de culto, promover a tolerância a todas as religiões e também àqueles que escolhem não ter uma religião. Ademais, assim como a ideia de secularização, a de laicidade também possui mais de um entendimento. Os dois conceitos para o autor: "[...] Contêm acepções análogas e intercambiáveis. E nenhum deles é mais ou menos preciso que seu par" (MARIANO, 2011, p.245).

Logo, secularização pode ser definida como a redução da presença das crenças e práticas religiosas nas instituições políticas, jurídicas, sociais, ao passo que a religião seria resguardada a vida privada. Entretanto, Mariano (2011) explicou que a separação entre a Igreja Católica e o Estado brasileiro, em meio ao surgimento da República, não extinguiu as vantagens e regalias católicas e nem mesmo a discriminação, deslegitimação e depreciação por parte do Estado às outras expressões religiosas, sobretudo, as espíritas e afro-brasileiras. Recorrendo as palavras do autor:

\begin{abstract}
A separação Igreja-Estado no Brasil, estabelecida com o advento da República, não pôs fim aos privilégios católicos e nem a discriminação estatal e religiosa às demais crenças, práticas e organizações mágicoreligiosas, sobretudo às do gradiente espírita. Neutralidade estatal zero em matéria religiosa. Mas a discriminação não restringiu-se de modo algum à atuação de agentes e instituições estatais. Agentes públicos e privados, cada qual à sua maneira, discriminaram abertamente os cultos espíritas e afrobrasileiros (MARIANO, 2011, p.246).
\end{abstract}

Dessa forma, como vimos anteriormente com Monteiro (2006) e Camurça (2009) Mariano (2011) também destacou a maneira como a Igreja Católica foi tida como modelo do que podia ser concebido como religião e o que não. Destarte, o autor acrescentou outras informações importantes a fim de conhecermos qual foi à postura da Igreja Católica mediante o crescimento dos movimentos pentecostais e umbandistas 
entre as décadas de 1940 e 1950 no cenário religioso brasileiro.

Um dos exemplos da lógica concorrencial que se estabeleceu entre os grupos de católicos e protestantes e que iria se intensificar com o passar dos anos, ocorreu já em 1939, quando a Igreja Católica criou o Departamento de Defesa da Fé, o qual: “[...] Implementou uma política de oposição ao protestantismo, em nome da defesa da nação católica" (ROLIM apud MARIANO, 2011, p.247). Desde lá a Igreja Católica tem criado diversas estratégias para contrapor o crescimento de outras religiões na esfera pública, lócus que até então prevalecia à hegemonia católica.

Nesta perspectiva, segundo Mariano (2011) na década de 1990 os segmentos católicos passaram a investir consideravelmente nos meios de comunicação de massa, sobretudo, na televisão, campo que não detinham presença expressiva se comparada aos grupos pentecostais ${ }^{6}$ : "Em 1995, por exemplo, possuía apenas uma emissora de televisão. Daí em diante, deu-se o milagre da multiplicação de emissoras e redes de tevê católicas [...]" (MARIANO, 2011, p.249). Não convergente, se os católicos adentraram o espaço midiático a fim de disputar a adesão de fieis com os setores pentecostais, estes últimos ingressaram na arena política, o que antes condenavam, a fim de defender seus interesses, disseminar seus valores morais bem como não perder benefícios obtidos junto ao Estado Brasileiro a partir da Constituinte de 1987.

\begin{abstract}
Os pentecostais abandonaram sua tradicional auto exclusão da política partidária, justificando seu inusitado ativismo político - antes proibitivo, porque tido como mundano e diabólico - com a alegação de que urgia defender seus interesses institucionais e seus valores morais contra os adversários católicos, homossexuais, macumbeiros e feministas na elaboração da carta magna. Para tanto, propuseram-se as tarefas de combater, no Congresso Nacional, a descriminalização do aborto e do consumo de drogas, a união civil de homossexuais e a imoralidade, de defender a moral cristã, a família, os bons costumes, a liberdade religiosa e de culto [...] (MARIANO, 2011, p.251).
\end{abstract}

Neste sentido, Trevisan (2013) explicou que a frente parlamentar evangélica é formada por políticos religiosos de diferentes igrejas e partidos que se unem para assegurar o cumprimento de seus interesses e, mais amplamente, das denominações religiosas que representam. Comumente suas propostas possuem caráter de propagar a moral cristã e, assim, combater os "desvios" que estão em desacordo a ela como, por

\footnotetext{
${ }^{6}$ Sobre este assunto, Leonildo Silveira Campos no texto: "Evangélicos, pentecostais e carismáticos na mídia radiofônica e televisiva" nos traz contribuições importantes.
} 
exemplo, a criação do Estatuto da Família ${ }^{7}$ que só reconhece como arranjo familiar aqueles formados por um homem e uma mulher, logo, a união entre pessoas do mesmo sexo é repudiada e desconhecida legalmente pela bancada evangélica.

Entendidos como uma espécie de "guardiões da moral e dos bons costumes", os políticos religiosos convertem seus fiéis também em eleitores a fim de angariar apoio para conquistar seus mandados e, posteriormente, os mobilizam a participar de manifestações públicas como a Marcha para Jesus, a promover abaixo assinados, contra quaisquer avanços que as minorias sociais consigam alcançar na arena política ou a toda possibilidade de inclusão destes segmentos em outros espaços públicos, como a mídia e suas novelas e propagandas que nos últimos anos tem retratado casais homossexuais e cuja reação destes grupos religiosos tem sido a desaprovação, o boicote ${ }^{8}$ sob o argumento de gerarem a decadência dos "bons costumes".

Trevisan (2013) entendeu que as ações da bancada evangélica só ganham força no Congresso Nacional devido ao conservadorismo que ali existe como um todo e da sociedade civil que se identifica com as propostas de orientação conservadora. É perceptível o juízo de valor entre o "bom/mal", o "certo/errado" o “aceitável/condenável" de base religiosa que orienta seus projetos políticos. Neste sentido, Patrocínio (2014) pontuou que a religião não se restringe apenas aos espaços físicos, como as igrejas, ela também interpenetra em locais subjetivos e subsidiam ideias, ideologias, visões de mundo.

Diante disso, não tem sido incomum encontrar fundamentações religiosas para a disseminação de preconceitos em diferentes dimensões como a homofobia, o racismo, a xenofobia entre outras formas de violência como o machismo, a defesa da pena de morte. Estas têm sido algumas das bandeiras que o conservadorismo brasileiro resguarda e reproduz. Segundo Patrocínio (2014) em estudo das reflexões de Pierucci, um das características do pensamento conservador é o moralismo, embora, saibamos que o conservadorismo não é uma corrente homogênea.

Assim, esclarece os autores, que o moralismo é disseminado na sociedade brasileira por meio dos meios de comunicação de massa, mais especificamente, os

\footnotetext{
$7 \quad$ Ver: http://noticias.uol.com.br/politica/ultimas-noticias/2015/09/24/comissao-da-camara-aprovaparecer-sobre-estatuto-da-familia.html

Ver: $\quad$ http://noticias.terra.com.br/brasil/malafaia-pede-boicote-a-o-boticario-apos-anuncio-comgays,d8cc3c2ae6a21e7f3a37f137810409f6adatRCRD.html
} 
jornais policiais sensacionalistas que alastram sociedade a fora os sentimentos de insegurança, impunidade além de gritarem ideias como: "bandido bom é bandido morto" e "direitos humanos para humanos direitos". Outra fonte de moralismo tem sido as vinculadas às religiões protestantes que criam normas de conduta para os indivíduos que não devem ser descumpridas sob pena de "desagradar a Deus". O padrão normativo é o homem branco, heterossexual e cristão e o modelo de família é o tradicional e patriarcal.

Dito isto, realizamos uma pesquisa ${ }^{9}$ em parceira do LERR com o OBEDUC de Ciências Sociais, ambos vinculados a UEL que teve como um dos seus objetivos verificar se a hipótese de que o pensamento conversador está (re)emergindo ${ }^{10}$ na sociedade brasileira se verificava. Deste modo, foram aplicados questionários a estudantes e professores de escolas públicas de Londrina sobre adesão religiosa, ditadura militar e concepção de família. Para nossa análise utilizaremos algumas das questões respondidas por 61 participantes da pesquisa na Escola Estadual Professora Lúcia Barros Lisboa e por outros 46 pesquisados do Centro Estadual de Educação Profissional (CEEP) Professora Maria do Rosário Castaldi.

No mais, torna-se importante salientar que a escolha para que a pesquisa fosse realizada em escolas não foi sem propósitos. Acreditamos que a escola é um espaço sui generis para a convivência entre os diferentes, isto porque, possibilita o contato entre indivíduos de diferentes classes sociais, com múltiplas crenças religiosas, de grupos étnico-raciais distintos, que trazem suas experiências e formas de pensar, crer, viver divergentes ao mesmo tempo em que a escola é uma instituição social que não está alheia aos fenômenos sociais que acontecem fora dela, nem mesmo as ideias e valores dominantes compartilhados na sociedade.

Os sujeitos escolares constroem suas (pré)noções e (pre)conceitos entre os diferentes mundos culturais que freqüentam e que acabam por se encontrar também na escola que é um destes habitats de significado ${ }^{11}$, cabendo a ela a função de reproduzi-los ou desconstruí-los. Com base neste entendimento, perguntamos aos alunos do ensino médio e professores das duas escolas: Qual sua opinião sobre a união de pessoas do

\footnotetext{
${ }^{9}$ Os dados apresentados não foram sistematizados estatisticamente.

${ }^{10}$ As manifestações populares pelo país, cujos participantes pedem o impeachment da presidente Dilma Rousseff e a volta da ditadura militar é um exemplo.

${ }^{11}$ Em referência a Ulf Hannerz.
} 
mesmo sexo? Entre os 46 participantes da pesquisa no Centro Estadual de Educação Profissional Professora Maria do Rosário Castaldi 26 deles se declararam contrários $(56,5 \%)$ ao passo que 16 deles são a favor $(34,7 \%)$ e 04 disseram não ter opinião formada sobre o assunto $(8,6 \%)$.

Já na Escola Estadual Professora Lúcia de Barros Lisboa entre os 61 pesquisados 29 declararam-se favoráveis a união homoafetiva (47,5\%), 17 deles disseram não ter opinião formada $(27,8 \%)$ e $15(24,5 \%)$ sujeitos se relevaram contrários. No entanto, se juntarmos o contingente dos que dizem não ter opinião formada com os que são declaradamente contra teremos um número superior aos que são favoráveis $(52,3 \%)$. Os gráficos a seguir nos auxiliam a melhor visualizar estes números:

Gráfico 1. CEEP Professora Maria do Rosário Castaldi

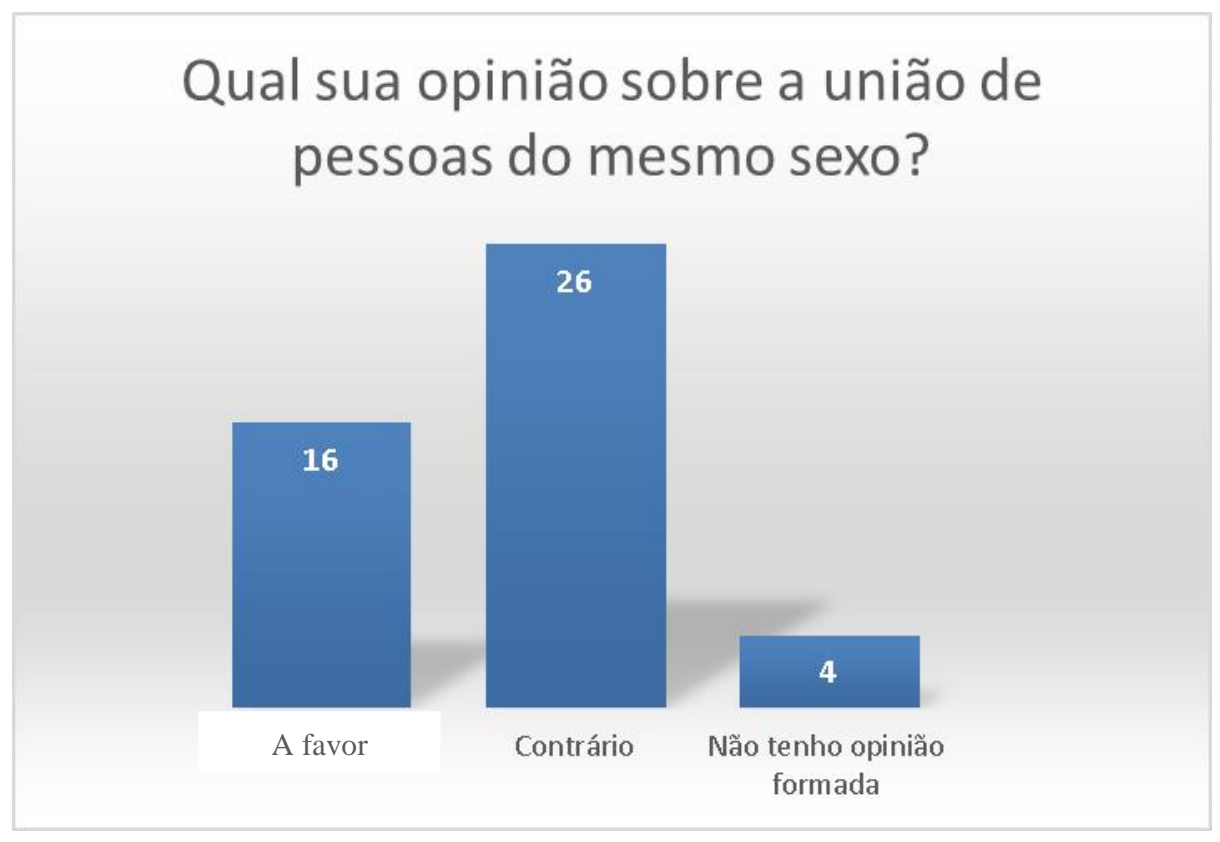

Fonte: Autoras

Gráfico 2. Escola Estadual Professora Lúcia Barros Lisboa 


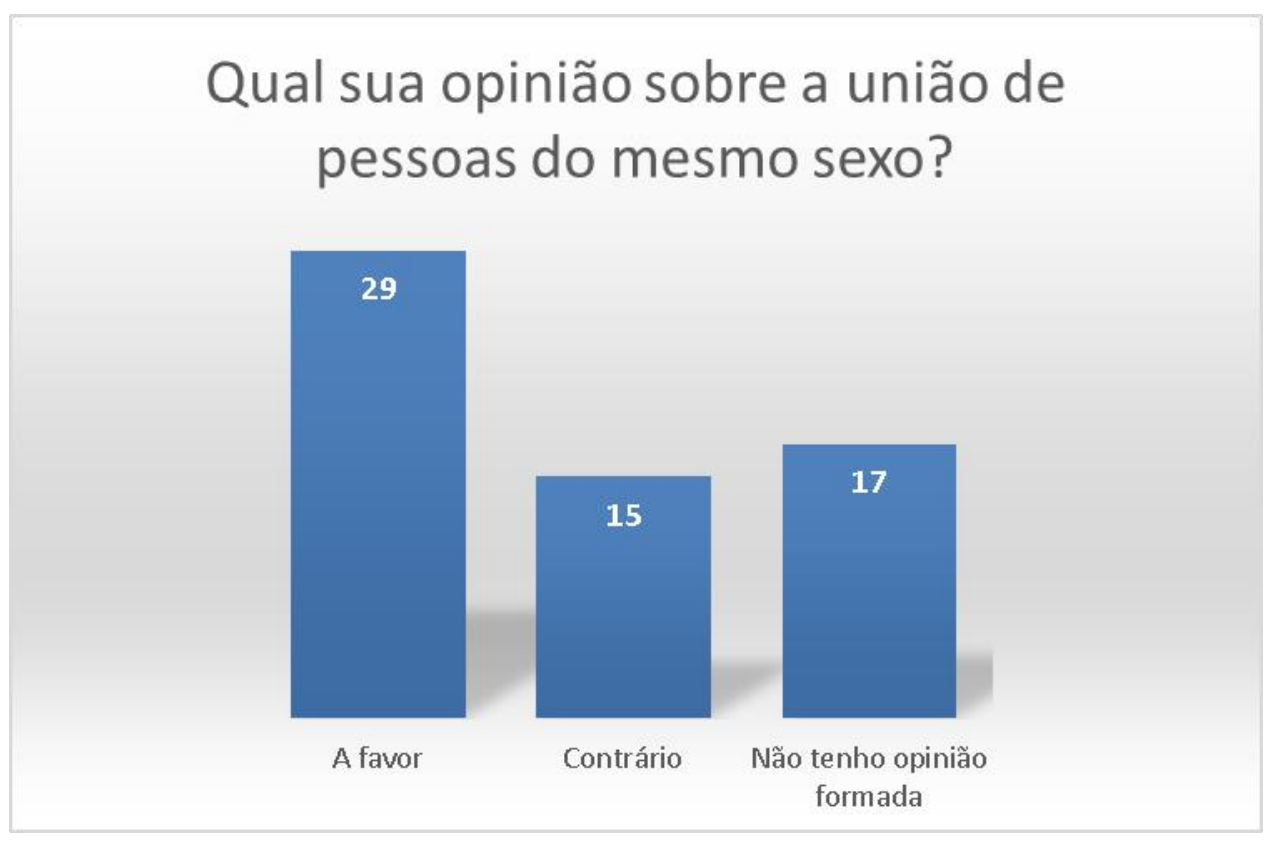

Fonte: Autoras

Percebemos, então, que os participantes da pesquisa em ambas as escolas partem de uma dificuldade em reconhecer as diferenças, haja vista que majoritariamente revelam-se contrários a união entre pessoas do mesmo sexo. Com isto, reforçam uma visão homogênea de sociedade que desvaloriza os diferentes, os que "estão fora do padrão" socialmente dado. Ademais, este entendimento homogeneizante reproduz uma concepção (mono)cultural de educação que acaba por moldar os indivíduos aos valores, regras, pensamentos hegemônicos, sendo estes, como dito anteriormente, em grande medida produtos de uma moralidade religiosa na sociedade brasileira e que estão presentes nas esferas públicas tais como a política e as escolas.

Retomando as contribuições de Mariano (2011) a partir da promulgação da Constituição Federal de 1988 as rivalidades e tensões entre as igrejas cristãs e os grupos laicos que defendem a laicidade estatal na contramão da interferência religiosa nos setores públicos tais como a educação, saúde, políticas públicas e nos órgãos estatais cresceram. Com concepções diversas sobre o que vem a ser um Estado laico bem como sobre qual o lugar que a religião deve ocupar na sociedade brasileira, as primeiras visam adentrar o espaço público, embora em discurso também defendam a laicidade, já os segmentos laicos procuram a efetividade de seus direitos sociais para além da regulamentação da moral religiosa, defendem um ensino público sem intervenção de quaisquer religiões e a limitação dos grupos religiosos no campo político. Ambos 
constituem forças sociais antagônicas que se enfrentam pelo controle do poder no cenário político brasileiro.

Deste modo, torna-se evidente para Mariano (2011) que a "laicidade a brasileira" não promoveu no Brasil um processo de secularização no qual ocorreria a privatização da religião, ao contrário, o que vemos são católicos e evangélicos disputando não só seguidores para suas igrejas, mas também cargos políticos como meio de orientar as ações do Estado a fim de que ele atenda suas demandas e traga vantagens a estes segmentos religiosos específicos além de conquistar espaços para a reprodução de suas moralidades religiosas.

\section{As tensões entre religiões nas escolas públicas}

Tendo em vista a manutenção de uma moralidade religiosa cristã, sobretudo, católica no Brasil orientaremos nossas reflexões pelos seguintes questionamentos: a moral religiosa encontra-se presente dentro das escolas públicas somente de forma subjetivada pelas representações e práticas dos indivíduos? Quais os significados dos símbolos religiosos nos espaços escolares públicos?

De acordo com as reflexões de Cecchetti (2012) sobre as relações entre as religiões e a educação no Brasil, estas devem ser vistas de modo a desmistificar as bases homogeneizantes sobre as quais foram formadas. Segundo ele, no dia a dia das escolas públicas o catolicismo tornou-se o parâmetro para as demais crenças religiosas, expressando-se majoritariamente, de modo implícito, uma vez que, ao contrário de outras matrizes religiosas, não causa estranhamento aos agentes escolares. Nas palavras do autor: "[...] o catolicismo constitui a norma religiosa perante a qual as outras manifestações religiosas representam apenas o desvio" (CECCHETTI, 2012, p.7).

Deste modo, podemos considerar os crimes de intolerância e discriminação religiosa como decorrentes da imposição do catolicismo aos outros grupos religiosos, o que como já dito anteriormente ocorre desde os primórdios do Brasil colônia, período em que, por exemplo, os terreiros de candomblé foram condenados e perseguidos ${ }^{12}$.

Também neste sentido, o livro: "Educação nos terreiros - e como a escola se

\footnotetext{
${ }^{12}$ Sobre isto, Roger Bastide em: “As religiões africanas no Brasil: Contribuição para uma Sociologia das Interpenetrações de Civilizações" nos traz contribuições importantes.
} 
relaciona com o candomblé" ${ }^{\prime 13}$ (2012), resultado de 20 anos de pesquisa da professora Stela Guedes da Universidade do Estado do Rio de Janeiro (UERJ) nos trouxe dados que corroboram com as reflexões de Cecchetti (2012). De acordo com a pesquisadora que procurou analisar o preconceito contra as religiões de matriz africana no universo escolar, bem como, as dificuldades para o cumprimento da lei $10.639^{14}$, uma de suas verificações foi que para os alunos de religiões afro-brasileiras a escolas é o local onde mais se sentem discriminados, isto porque, a escolas públicas ainda têm a função de “catequizar", converter e não apenas no que tange a opção religiosa, pois todos os considerados "diferentes" são submetidos à ideologia dominante que padroniza os indivíduos inculcando-lhes valores dominantes e normativos sobre as concepções de família, sexualidade, padrões de beleza, religião.

Dessa forma, ao disseminar e reforçar esta hegemonia católica nas escolas públicas brasileiras, que valoriza o catolicismo como religião universal, os contextos escolares podem contribuir para a segregação de outros coletivos religiosos bem como para a demonização das práticas e crenças religiosas destes grupos, uma vez que não reconhecem as diversas religiões com suas linguagens, códigos, ritos, símbolos peculiares, isto é, não compreendem as diferentes expressões religiosas como fenômenos culturais que não devem ser comparados, nem hierarquizados, de modo que:

\begin{abstract}
Sem o devido preparo para acolher a diversidade religiosa, em muitas escolas públicas, os ritos e ritmos escolares colaboram para a manutenção dos rótulos e preconceitos perante a diversidade de expressões religiosas e não religiosas. O calendário escolar restringe-se a comemoração das datas e festas previstas na liturgia cristã, não raro, contando com a presença de seus líderes na realização de celebrações, comemorações e formaturas (CECCHETTI, 2012, p.06).
\end{abstract}

Com base neste entendimento, identificamos a promoção de um "monoculturalismo religioso" de orientação, sobretudo, católica, dentro dos espaços escolares. Assim, de acordo com Cecchetti (2012) podemos encontrar a supremacia católica nos ambientes escolares de três maneiras que se complementam: 1) de forma institucionalizada através de "compadrios" entre a comunidade escolar e as lideranças religiosas católicas: "Espaço não concedido igualmente aos pais-de-santo, médiuns e pastores evangélicos, por exemplo" (CECCHETTI, 2012, p.07), 2) de maneira objetiva,

13 Ver: http://portal.aprendiz.uol.com.br/2015/05/12/escola-e-o-espaco-onde-criancas-de-religioes-afromais-se-sentem-discriminadas-afirma-pesquisadora/

${ }^{14}$ Sancionada em 2003 pelo governo federal a lei prevê o ensino da cultura e da história afro-brasileira e africana nas escolas. 
através dos símbolos e imagens religiosos católicos no espaço escolar assim como comemorações como Páscoa, Natal ou missas nas formaturas e 3) de modo incorporado nos agentes escolares, o que se verifica através de seus valores, visões de mundo.

Tendo em vista estes apontamentos, questionamos alunos do ensino médio e professores das escolas Escola Estadual Lucia Barros Lisboa e Centro Estadual de Educação Profissional Professora Maria do Rosário Castaldi com a seguinte pergunta: $O$ que você acha das manifestações ou de símbolos religiosos na escola? Na primeira escola dos 61 questionários respondidos 21 participantes declararam concordar $(34,4 \%)$, 20 sujeitos se disseram indiferentes $(32,7 \%), 19$ respondentes discordaram $(31,1 \%)$ e 01 não respondeu (1,6\%). Já na segunda escola dos 46 participantes da pesquisa 21 disseram ser indiferentes (45,6\%), 17 declaram concordar (36,9\%), 05 são contrários $(10,8 \%)$ e 03 não responderam $(6,5 \%)$.

Torna-se ainda importante destacar que entre os 61 participantes da pesquisa na Escola Estadual Lúcia Barros Lisboa 50 sujeitos declararam ter alguma religião (81,9\%), sendo que destes 24 disseram ser católicos (48\%) e outros 24 indivíduos revelaram-se membros de igrejas de vertentes do protestantismo, (48\%) tais como: Igreja Evangélica Presbiteriana, Igreja Evangélica Batista, Igreja Assembleia de Deus, Igreja Congregação Cristã do Brasil, Igreja O Brasil para Cristo, Igreja Universal do Reino de Deus, Igreja Deus é Amor, Igreja Nova Aliança, Testemunha de Jeová. Apenas 02 participantes dos 50 respondentes religiosos não responderam qual religião possuem (4\%) e 11 indivíduos declararam não ter religião $(18,1 \%)$. Observa-se que nesta escola, entre os sujeitos pesquisados, há a predominância de cristãos que em sua maioria concorda com a existência de manifestações e símbolos religiosos na escola. De acordo com o gráfico abaixo: 


\section{Gráfico 3. Escola Estadual Lúcia Barros Lisboa}

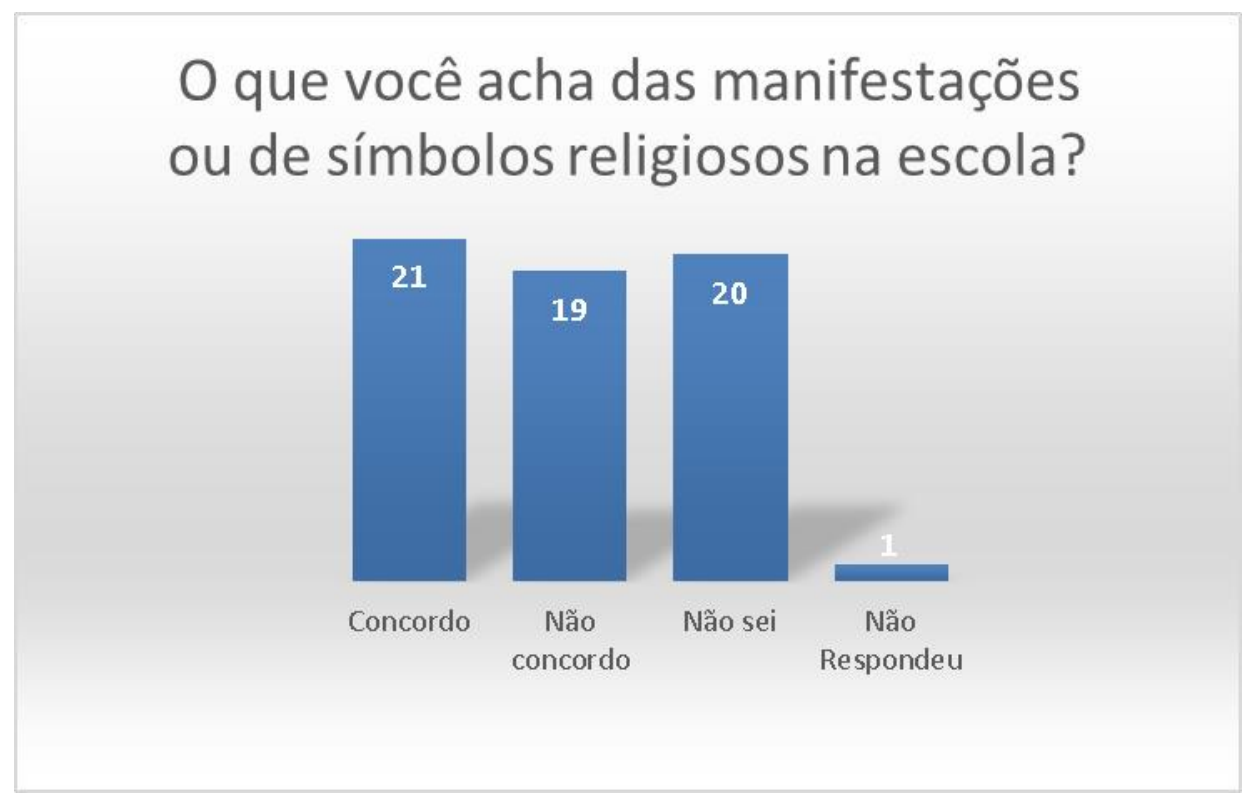

Fonte: Autoras

$\mathrm{Na}$ outra escola CEEP Castaldi, o cenário religioso formado predominantemente de cristãos se repete entre os participantes da pesquisa, de modo que entre os 46 respondentes 38 declararam possuir alguma religião $(82,6 \%)$ e 08 falaram não ter religião alguma (17,3\%). Entre os sujeitos religiosos 22 revelaram ser católicos (57,8\%), 16 membros de igrejas protestantes (42,1\%) tais como Igreja Evangélica Batista, Igreja Evangélica Adventista, Igreja Assembleia de Deus, Igreja Congregação Cristã do Brasil, Igreja O Brasil para Cristo, Igreja de Jesus Cristo dos Santos dos Últimos Dias, Igreja Bola de Neve.

Nesta escola a maioria dos sujeitos pesquisados declarou-se indiferente a presença de manifestações e símbolos religiosos nas escolas com diferença inexpressiva daqueles que são favoráveis ao passo que os contrários as expressões religiosas no ambiente escolar constituem um universo pequeno quando comparado aos indecisos e aos que concordam. O gráfico a seguir nos auxilia a melhor visualizar estes números: 


\section{Gráfico 4. CEEP Castaldi}

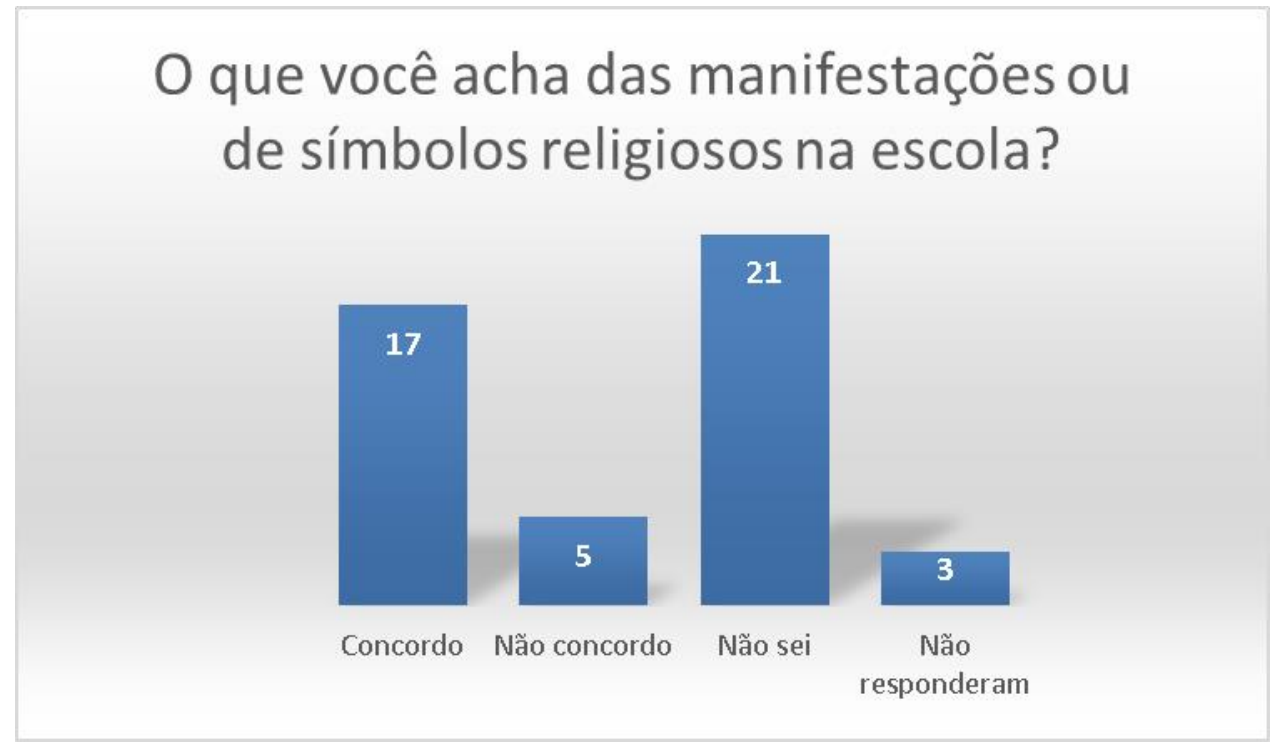

Fonte: Autoras

Isto posto, perguntamos aos que se disseram favoráveis quais religiões poderiam ter símbolos religiosos na escola. Na Escola Estadual Lúcia Barros Lisboa 18 participantes responderam que todas e 04 disseram que apenas algumas religiões, sendo que destes 03 falaram que concordam apenas com a existência dos símbolos religiosos católicos e 01 com os objetos religiosos evangélicos.

\section{Gráfico 5. Escola Estadual Lúcia Barros Lisboa}

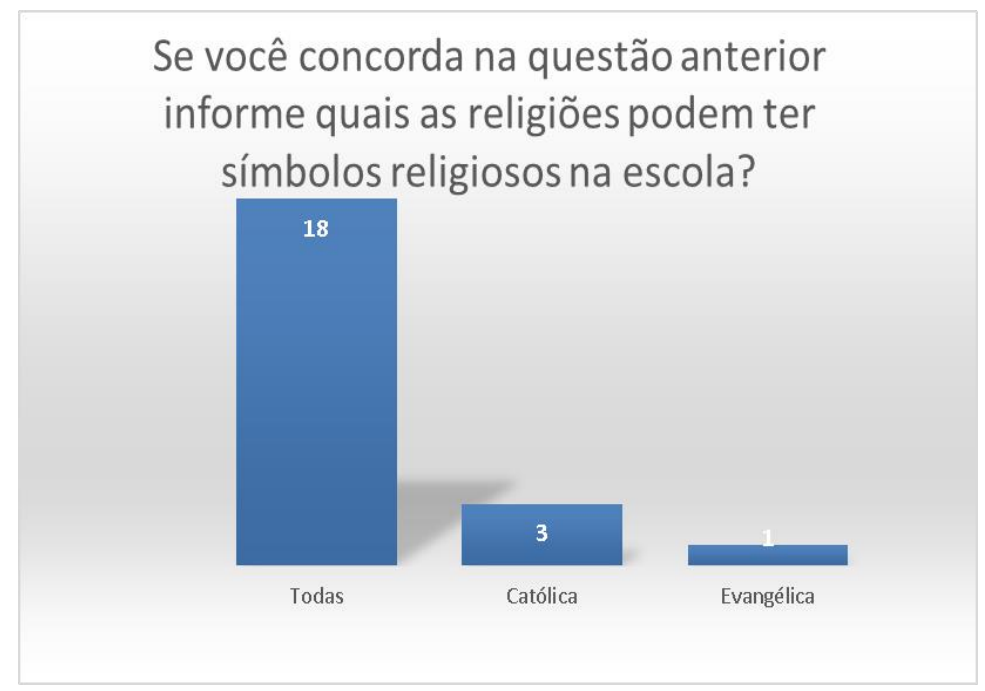

Fonte: Autoras 
Já na Escola CEEP Castaldi dos participantes da pesquisa que concordam com a presença dos símbolos religiosos na escola apenas 02 deles disseram que podem ser de todas as religiões, 03 sujeitos disseram favoráveis apenas a existência dos símbolos religiosos católicos, outros 03 apenas aos das religiões evangélicas sem especificar qual denominação religiosa, 01 disse concordar apenas com a presença dos objetos religiosos da Igreja Adventista, 01 aos da Comunidade Evangélica Deus Vivo e outros 07 não responderam.

\section{Gráfico 6. CEEP Castaldi}

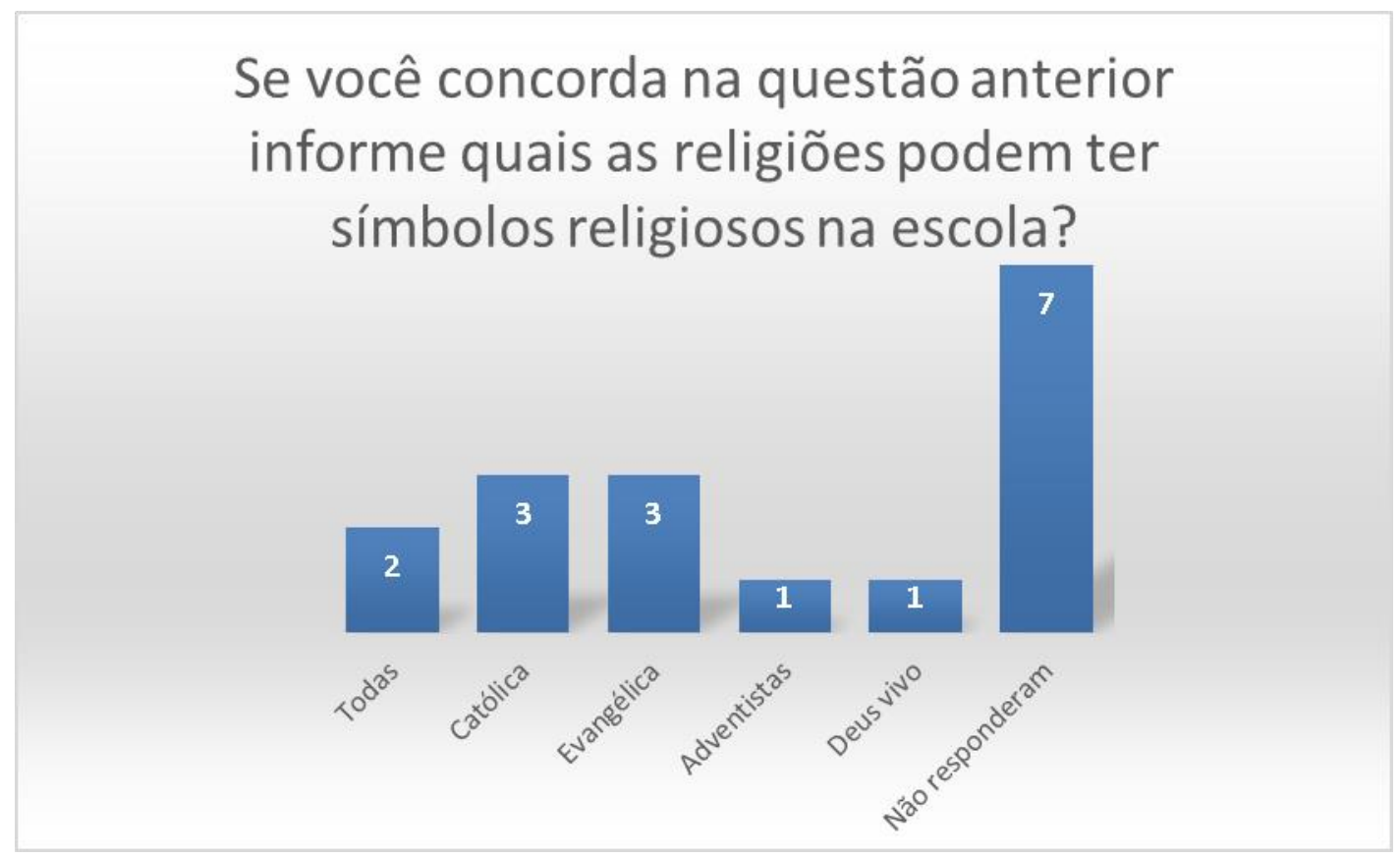

Fonte: Autoras

Nota-se, então, que as reflexões de Cecchetti (2012) segundo as quais os objetos religiosos cristãos são predominantes nas escolas públicas brasileiras se relacionam as duas escolas, haja vista que os alunos e professores pesquisados, declarados católicos e protestantes, restringem a permissibilidade dos símbolos religiosos a suas denominações religiosas cristãs.

Nesta perspectiva, de acordo com Júnior (2012) os símbolos religiosos cristãos, como crucifixos, terços, altares, bíblias nos locais públicos podem ser encontrados em todos os momentos históricos da vida política brasileira, ou seja, no período colonial, imperial chegando ao regime republicano, devido ao característico catolicismo popular luso-brasileiro encontrado por aqui que além deles também tem como peculiaridade as 
festas, romarias e procissões.

Segundo ele, os crucifixos em espaços públicos, tais como escolas, universidades, tribunais são fixados em lugar de destaque, visíveis aos que chegam e na maioria das vezes passam despercebidos. Para o autor a razão desta naturalização dos símbolos religiosos católicos ocorre porque já se tornaram um costume, uma tradição que expressa a "cultura cristã brasileira", não por acaso usualmente estarem localizados próximos a símbolos cívicos, como a bandeira do Brasil. Esta estratégia remete a ideia de uma cultura nacional baseada no cristianismo.

Ainda para Júnior (2012) nas últimas décadas símbolos de outras expressões religiosas, como as de orientação evangélica, também começaram a surgir nos espaços públicos, o que revela o fortalecimento deste segmento religioso nos últimos anos assim como seu desejo em conquistar os espaços públicos, haja vista o movimento organizado de grupos pentecostais na política brasileira.

Todavia, segundo o autor, nestes locais públicos encontramos predominantemente símbolos cristãos, que tendem a representar os estratos católicos e evangélicos somente e, sobretudo, os primeiros, contribuindo, assim, para criação de uma concepção do Brasil enquanto "pátria cristã": "Expressões como pátria cristã, nação cristã, cultura cristã, cultura católica, povo religioso, povo espiritualista, tradição cristã e outras semelhantes são abundantemente utilizadas pelos atores favoráveis à afixação de símbolos religiosos em ambientes estatais" (JUNIOR, 2012, p.63). A imagem a seguir é um exemplo da presença dos símbolos religiosos cristãos em uma escola pública na cidade de Londrina-PR.

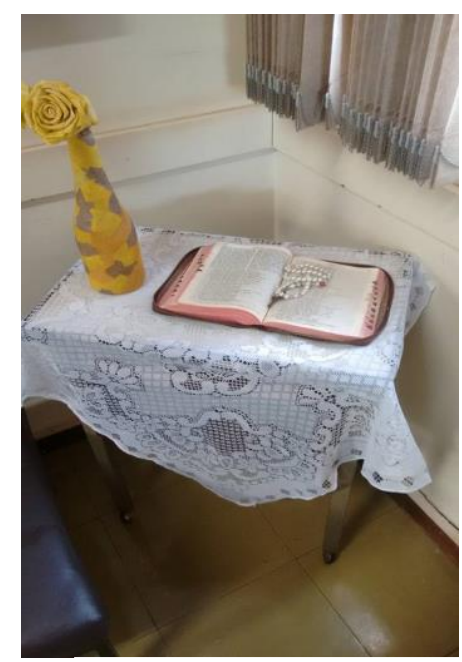

Fonte: Autoras 
Júnior (2012) informou que de uma de série de entrevistas que realizou com profissionais do direito durante o $6^{\circ}$ Congresso de Magistrados Estaduais, realizado no Rio Grande do Sul, em 2005, a maioria declarou não considerar que a presença dos símbolos religiosos nas esferas públicas fira os princípios de laicidade estatal, isto porque, para eles, o crucifixo não possui apenas um sentido religioso, porém civilizacional que inspira valores de justiça, paz social e estes devem orientar os espaços jurídicos, políticos e o comportamento dos indivíduos. Nota-se que o cristianismo, sobretudo o catolicismo, é tido como fonte das normas morais e sociais para a vida em coletividade: "O cristianismo e principalmente o catolicismo é percebido como um baluarte da civilização e da moralidade, o guardião da memória coletiva e da tradição, bem como um elemento crucial em nossa formação social e cultural” (JUNIOR, 2012, p.67).

No entanto, esclareceu o autor que esta tentativa de dar outro sentido ao símbolo que não o religioso é uma forma de defendê-lo, de manter as influências religiosas nos espaços públicos. De igual maneira por meio da leitura de trechos bíblicos no inicio das sessões das assembleias legislativas estaduais, das câmaras municipais e da câmara federal o texto religioso é tido como orientador de princípios universais, para todos independente de sua religião, isto é, os ensinamentos bíblicos são defendidos para o desenvolvimento da nação, para tornar os indivíduos mais humanos, caridosos, para que tenham fé, dignidade, amor ao próximo.

Observa-se, então, que de acordo com este entendimento a vida política deve ser orientada pelo sagrado: “Ademais, são acionadas motivações e intenções seculares para justificar pretensões de fundo religioso. A colocação da bíblia, assim como a afixação do crucifixo não buscaria evangelizar e transmitir elementos puramente religiosos" (JUNIOR, 2012, p.73). Dito de outra maneira, a palavra de Deus é vista como base para orientar o comportamento de todos.

Todavia, segundo o autor, a presença dos símbolos religiosos nos espaços públicos deve ser considerada como uma estratégia das religiões para se apropriarem deles a fim de fortalecer suas respectivas identidades religiosas. Em outras palavras, compreendermos os crescentes conflitos entre católicos e evangélicos em disputa pelas esferas públicas requer considerarmos a perda da hegemonia católica no cenário 
religioso brasileiro, a expansão dos segmentos protestantes e seus campos como forças sociais e políticas que buscam o reconhecimento de suas práticas, crenças, símbolos, rituais, dogmas, valores e interesses.

Refletindo um pouco mais acerca da ausência da laicidade na educação púlica brasileira, a disciplina de ensino religioso é outro exemplo. Segundo Patrocinio (2014) a presença do ensino religioso nas escolas se distancia da concepção de um Estado laico e paradoxalmente a disciplina foi instituída pela Constituição de 1988, a mesma que buscou inspirar a ideia de laicidade republicana. Além disso, outra problemática que envolve o ensino religioso é a falta de inexistir uma orientação curricular nacional oficial $^{15}$, ou seja, não há um currículo que oriente quais os conteúdos devem ser ensinados a fim de dar suporte a prática do professor. Diante disso, a disciplina tem sido um campo extremamente lucrativo para o mercado editorial e comumente tem assumido perspectiva confessional de caráter proselitista.

\section{Considerações Finais}

Este trabalho buscou problematizar a teoria da secularização e o seu pressuposto de abandono ou mesmo enfraquecimento das religiões na atualidade, haja vista que na sociedade brasileira a importância dada às referências religiosas, as experiências místicas na vida dos indivíduos ainda é constante bem como no âmbito público é possível identificarmos o compartilhamento de uma moral religiosa, sobretudo, cristã que desempenha o papel de organizadora da vida social de maneira a orientar o comportamento dos indivíduos e estabelecer regras e padrões normativos entre o "certo" e o "errado".

Logo, a separação oficial entre a Igreja Católica e o Estado brasileiro, o que deu origem a ideias de princípios seculares acerca da política, não levou a extinção da religião e nem mesmo a perda de sua força social, ao contrário, que se viu foi o surgimento de novas expressões religiosas. O cenário religioso brasileiro marcado pelo sincretismo, pelas “contaminações mútuas” entre as diferentes religiões é um fenômeno que tem se expandido de modo que os indivíduos unem elementos de denominações

\footnotetext{
15 Está em discussão a aprovação da BNCC (Base Nacional Comum Curricular) criada pelo MEC (Ministério da Educação). Nesta, há orientação para todas as disciplinas curriculares, de modo que segundo a apresentação do componente curricular ensino religioso é apresentado com a necessidade de desconstruir seu papel proselitista.
} 
distintas e compõem a sua religião para uma determinada conjuntura e sem que isto leve necessariamente a mudança em plano institucional. Como um mosaico religioso os sujeitos vão juntando elementos e vivenciando experiências religiosas díspares para determinados momentos.

Deste modo, as religiões no Brasil têm constituído um campo em disputa, cujas tensões se dão pela concorrência por fieis e também pela apropriação dos espaços públicos, onde a participação das religiões tem sido cada vez mais freqüente. A estratégia de estar presente nas esferas públicas tem seus propósitos, dentre os quais, além da expansão de seus membros e reconhecimento de suas práticas e ritos, o anseio pela disseminação de sua moralidade nestes locais coletivos, ou seja, de seus modos de crer e interpretar o mundo.

Diante disso, procuramos refletir, ainda que inicialmente, sobre a disseminação desta moral religiosa e a presença de símbolos religiosos dentro das escolas públicas. Com isto, observamos que os universos escolares não estão adversos a esta permanência religiosa, sobretudo, cristã, cujos católicos e em menor medida as vertentes das religiões protestantes históricas, pentecostais e neopentecostais predominam enquanto grupo dominante também nestes locais, o que não quer dizer que não haja nas escolas alunos e professores espíritas, candomblecistas, umbandistas, budistas, ateus, entre outros segmentos religiosos, mas sim que estes são assimilados pela maioria, pelas religiões prevalecentes e, não raro são discriminados por esta e na maioria das vezes de forma velada.

Assim, é comum não revelarem seus verdadeiros pertencimentos a outros grupos religiosos para não serem estigmatizados. Embora legalmente vivamos em um Estado que constitucionalmente prevê a liberdade religiosa, os crimes de intolerância religiosa dentro das escolas e, mais amplamente, na sociedade não tem sido esporádicos.

Mediante estas considerações torna-se evidente que um dos desafios postos ao Estado brasileiro e em especial as escolas, como uma de suas esferas públicas, é o choque entre esta moralidade religiosa e o desenvolvimento de uma educação de perspectiva multicultural ${ }^{16}$, como base para uma sociedade, de fato, democrática, inclusiva para todos os grupos sociais. Esta deve ir além da tolerância às diferenças atingindo o reconhecimento dos estratos minoritários como sujeitos de direitos.

${ }^{16}$ São sugestões para leitura: Featherstone, 1997; Hall, 1997 e Candau, 1997. 
De toda sorte, debates sobre igualdade racial ${ }^{17}$, diversidade sexual ${ }^{18}$, pluralismo religioso $^{19}$ nas escolas são fundamentais, vide a resistência que estes assuntos ainda encontram pela comunidade escolar e, mais amplamente, pela sociedade civil que acabam por contribuir para que as escolas não reflitam a diversidade cultural latente na sociedade brasileira.

\section{.Referenciais}

CAMURÇA, Marcelo. Entre sincretismos e "guerras santas". Revista Usp. São Paulo, n. 81, março/maio 2009.

CECCHETTI, Elcio. Diversidade religiosa na escola pública: Presenças e Ausências. XII SEFOPER (Seminário Nacional de Formação de Professores para o Ensino Religioso). 13 a 15 de setembro de 2012. Manaus/AM.

JÚNIOR, Cesar Alberto Ranquetat. A presença da bíblia e do crucifixo em espaços públicos no Brasil: Religião, cultura e nação. In: A religião no espaço público: Atores e objetos. Ari Pedro Oro, Carlos Alberto Steil, Roberto Cipriani, Emerson Giumbelli, organizadores. - São Paulo: Terceiro Nome, 2012.

MARIANO, Ricardo. Laicidade à brasileira: católicos, pentecostais e laicos em disputa na esfera pública. Civitas: Revista de Ciências Sociais. Vol. 11, 2011.

MONTEIRO, Paula. Religião, Pluralismo e Esfera Pública no Brasil. Novos Estudos. São Paulo: CEBRAP, n. 74, mar 2006.

PATROCÍNIO, Luis Gustavo. Escola e Religiões: Estudo sobre desdobramentos das práticas religiosas no ambiente escolar e suas interfaces com a disciplina de ensino religioso. Dissertação de mestrado. Universidade Estadual de Londrina, 2014.

TREVISAN, Janine. A Frente Parlamentar Evangélica: Força política no estado laico brasileiro. Numen: Revista de Estudos e Pesquisa da Religião, Juiz de Fora, v. 16, n. 1, p. 581-609, 2013.

Recebido: 06/10/2016

Received: 10/06/2016

Aprovado: 01/11/2016

Approved: 11/01/2016

\footnotetext{
17 Ver: http://www.brasil247.com/pt/247/sp247/184129/Escola-que-negou-matr\%C3\%ADcula-a-meninonegro-\%C3\%A9-multada-por-racismo.htm

18 Ver: http://g1.globo.com/sp/sao-carlos-regiao/noticia/2015/06/metas-para-area-da-educacao-ignoramquestoes-de-genero-e-geram-polemica.html

19 Ver: http://educacao.uol.com.br/noticias/2014/09/03/rj-aluno-e-impedido-de-frequentar-escola-comguias-de-candomble.htm
} 